\title{
Analisis Potensi dan Permasalahan Pengembangan Wilayah Pesisir di Kecamatan Arosbaya Kabupaten Bangkalan Madura Provinsi Jawa Timur
}

\author{
[Analysis of Potential and Problem Development in Coastal Areas in Arosbaya \\ District, Bangkalan Madura District, East Java Province]
}

\author{
Ririn Rosita Hur, Toni Ruchimat, Yenni Nuraini
}

\author{
Program Studi Penyuluhan Perikanan, Politeknik Ahli Usaha Perikanan
} Jalan Cikaret No. 2 Bogor 16321, Jawa Barat

\begin{abstract}
Abstrak
Potensi sumber daya pesisir Indonesia sangat beragam, baik dari segi kualitas dan kuantitasnya, tetapi tanpa menyadari bahwa potensi tersebut sampai saat ini belum secara optimal dikembangkan dan dikelola sesuai dengan aturan kode etik perikanan yang bertanggung jawab (code of conduct for responsible fisheries/CCRF). Penelitian ini dilakukan pada bulan Oktober 2019 yang bertujuan untuk menganalisis potensi dan permasalahan pada pengembangan wilayah pesisir di Kecamatan Arosbaya Kabupaten Bangkalan Madura, Provinsi Jawa Timur. Analisis potensi dan permasalahan tersebut dilakukan dengan metode PRA melalui pengisian borang, yang berjumlah 42 responden sebagai sampel, terdiri dari 39 orang dibidang penangkapan, 2 orang dibidang budidaya ikan, dan 1 orang dibidang pengolahan hasil perikanan. Hasil penelitian menunjukkan bahwa Kecamatan Arosbaya merupakan kawasan potensial baik dibidang usaha perikanan dan ekosistem mangrove yang terbentang didalamnya. Pada pengembangan potensi tersebut, ditemukan beberapa permasalahan terkait dibidang usaha perikanan ataupun pada pelestarian ekosistem yang ada. Penelitian ini dapat dijadikan sebagai masukan dalam mewujudkan pengelolaan dan pengembangan secara co-management.
\end{abstract}

Kata Kunci: pengelolaan wilayah pesisir; sumber daya pesisir

\section{Abstract}

The potential of Indonesia's coastal resources varies greatly, both in terms of quality and quantity, but without realizing that this potential has not been optimally developed and managed in accordance with the code of conduct for responsible fisheries (CCRF). This research was conducted in October 2019 which aims to analyze the potential and problems in developing coastal areas in Arosbaya District, Bangkalan Madura District, East Java Province. Analysis of the potential and the problem was carried out by the PRA method by filling in forms, which numbered 42 respondents as samples, consisting of 39 people in the field of fishing, 2 people in the field of fish farming, and 1 person in the field of fishery product processing. The results showed that Arosbaya District is a potential area both in the field of fisheries and mangrove ecosystems that lie therein. In developing this potential, several problems were found related to the fisheries business or to the preservation of the existing ecosystem. This research can be used as input in realizing management and co-management development.

Keywords: coastal management and development; coastal resources

Penulis Korespondensi

Ririn Rosita Hur | ririnrositahur@gmail.com 


\section{PENDAHULUAN}

Indonesia memiliki kedaulatan meliputi ruang udara diatas laut teritorial serta dasar laut dan tanah dibawahnya. Lebar laut teritorial tersebut mencapai suatu batas yang tidak melebihi 12 (dua belas) mil laut, yang diukur dari garis pantai ke arah laut lepas dan ke arah perairan kepulauan untuk provinsi dan 1/3 dari wilayah kewenangannya untuk kabupaten/kota sesuai ketentuan yang berlaku. Batas laut ini menjadi sangat penting untuk pengelolaan potensi kelautan dan perikanan menuju negara maritim yang berdaulat (Muhktasor et al. 2016).

Pulau Madura adalah salah satu pulau yang dikenal cukup maju dari segi potensi perikanan dan kelautannya, baik dalam segmen usaha perikanan tangkap, budidaya, dan pengolahan hasil perikanan, serta dalam produksi garam rakyat. Kabupaten Bangkalan sebagai salah satu kabupaten yang memiliki potensi tersebut dan berada diantara 6051' - 7011' Lintang Selatan dan antara $112^{\circ} 40^{\prime}$ - 11308' Bujur Timur. Secara geografis, Kabupaten Bangkalan berada di ujung barat Pulau Madura yang terdiri dari 18 kecamatan yaitu Kamal, Labang, Kwanyar, Modung, Blega, Konang, Galis, Tanah Merah, Tragah, Socah, Bangkalan, Burneh, Arosbaya, Geger, Kokop, Tanjung Bumi, Sepulu, dan Klampis (BPS Kab. Bangkalan 2018).
Kecamatan Arosbaya merupakan salah satu wilayah pesisir yang berada di Kabupaten Bangkalan, serta memiliki potensi yang dapat dikembangkan dalam pembangunan perikanan. Potensi tersebut, tentunya dibutuhkan pengembangan agar dapat dimanfaatkan secara berkelanjutan. Upaya pengembangan ini berjalan secara optimal apabila para pemangku berkepentingan dapat mengelolanya dengan baik. Berdasarkan kondisi tersebut, maka penelitian ini bertujuan untuk menganalisis potensi dan permasalahan pengembangan wilayah pesisir, guna mengetahui keadaan sumber daya manusia (SDM), sumber daya alam (SDA), dan sumber daya penunjang (SDP).

\section{BAHAN DAN METODE}

Penelitian dilaksanakan pada tanggal 1 - 30 Oktober 2019, yang berlokasi di Kecamatan Arosbaya Kabupaten Bangkalan Madura Provinsi Jawa timur. Pengambilan data dilakukan melalui metode PRA, yang meliputi data primer dan data sekunder. Metode ini merupakan pendekatan dalam proses pemberdayaan dan peningkatan partisipasi masyarakat, yang tekanannya pada keterlibatan masyarakat dalam keseluruhan kegiatan pembangunan (Pratiwi 2007). Data primer adalah data yang diperoleh langsung dari objek yang diteliti yang bersumber dari narasumber 
atau objek yang diteliti seperti profil pelaku utama, penyuluh dan semua pihak yang mendukung kegiatan perikanan di Kecamatan Arosbaya. Data sekunder adalah data yang diperoleh secara tidak langsung yang berasal dari instansi-instansi pemerintah dan kajiankajian literatur.

Teknik penentuan sampel dilakukan dengan pendekatan Purposive Sampling, yaitu memilih responden baik individu maupun kelompok yang dinilai dapat mewakili dalam memberikan data dan informasi. Kecamatan Arosbaya memiliki 779 Rumah Tangga Perikanan (RTP) yang dijadikan sebagai populasi dalam penentuan sampel. Penentuan sampel dilakukan dengan menggunakan teknik penentuan sampel menurut Widodo (2008) dalam Nasriyah (2018) yaitu sampel diambil berdasarkan rumus slovinseperti yang terdapat pada penelitian(Setiawan 2007), dengan rumus sebagai berikut:

$$
\mathrm{n}=\frac{\mathrm{N}}{1+\mathrm{N}(\mathrm{e})^{2}}
$$

Ket: $(\mathrm{n})=$ ukuran sampel, $(\mathrm{N})=$ Populasi, dan (e) $=$ Tingkat kesalahan $(5 \%-20 \%)$

\section{Sampel yang digunakan} merupakan para pelaku utama perikanan yang berada di tiga desa potensial, yaitu Desa Arosbaya, Lajing, dan Tengket. Berdasarkan rumus tersebut, didapatkan sampel sebanyak 42 orang, yang terdiri dari 39 nelayan, 2 pembudidaya ikan, dan 1 orang yang bergerak disegmen usaha pengolahan hasil perikanan. Datadata yang diperoleh kemudian dilakukan tabulasi, pengolahan data dan analisis serta penginputan data menjadi sebagai bahan informasi untuk dapat disampaikan kepada masyarakat secara umum.

\section{HASIL DAN PEMBAHASAN \\ Hasil}

Kondisi Potensi dan Pengelolaan Pesisir

Kecamatan pesisir Arosbaya yang menjadi salah satu wilayah potensial dalam perikanan ini, terletak disebelah utara pusat Pemerintah Kabupaten Bangkalan, dengan orbitasi $\pm 13 \mathrm{~km}$ dan berada secara strategis dalam pengembangan pembangunan perikanan di Kabupaten Bangkalan. Batas-batas wilayah Kecamatan Arosbaya yaitu Sebelah Utara Kecamatan Klampis, Sebelah Selatan Kecamatan Burneh dan Bangakalan, Sebelah Timur - Kecamatan Geger, dan Sebelah Barat - Laut Jawa (BPS Kecamatan Arosbaya 2018). Wilayah ini, terletak pada ketinggian 0-4 MDPL, dengan rata-rata suhu udara $29-35^{\circ} \mathrm{C}$, serta memiliki luas $\pm 4245,207 \mathrm{Ha}$, yang terdiri dari wilayah pesisir/pantai, dataran rendah sampai dengan dataran tinggi yang mencakup 18 desa didalamnya. 


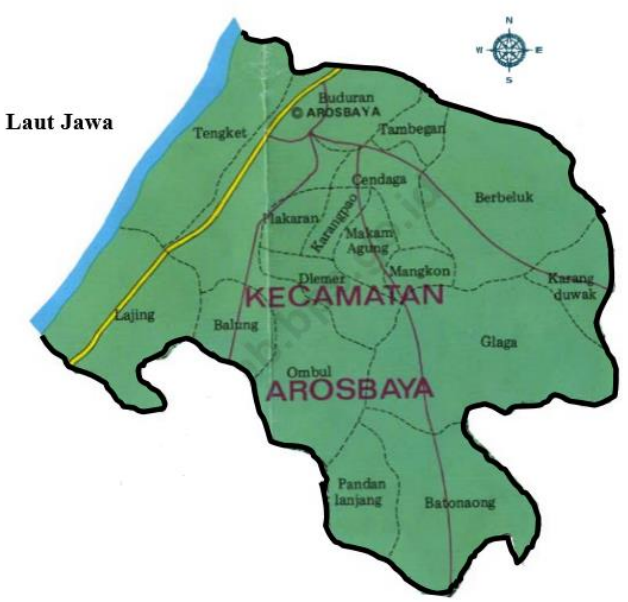

Gambar 1. Peta Wilayah Kecamatan Arosbaya

Sumber BPS Kec. Arosbaya (2018)

Tabel 2. Data Prediksi Luas Genangan Akibat Naiknya Muka Air Laut

\begin{tabular}{ccc}
\hline Tahun & Darat $(\mathbf{H a})$ & Genangan $\mathbf{( H a )}$ \\
\hline 20 & $124.699,16$ & 188,84 \\
50 & $123.934,96$ & 953,04 \\
\hline
\end{tabular}

Curah hujan rata-rata per-bulannya mencapai $1.619 \mathrm{~mm}$ dan rata-rata curah hujan per-harinya yaitu $17,04 \mathrm{~mm}$. Ciriciri iklim tersebut disebut sebagai iklim tropis menurut (Wirjohamidjojo dan Swarinoto, 2010). Berikut peta wilayah Kecamatan Arosbaya dapat dilihat pada Gambar 1.

Berdasarkan data BPS Kec. Arosbaya (2018), pemanfaatan ruang yang ada di Kecamatan Arosbaya terbagi menjadi: Kawasan Sawah $( \pm 2.131,93$ Ha), Tanah Tegalan ( $\pm 1.258,93 \mathrm{Ha}$ ), Bangunan/Pekarangan ( \pm 786,71 Ha), Kehutanan $\left(\begin{array}{lll} \pm & 0,00 & \mathrm{Ha}\end{array}\right)$ dan Pemamfaatan lainnya ( $\pm \quad 67,70 \quad \mathrm{Ha}$ ). Sebagian besar penggunaan lahannya digunakan dalam kegiatan pertanian. Sebagai wilayah pesisir, tentunya memiliki berbagai segmen kegiatan usaha perikanan yang meliputi: kegiatan usaha perikanan tangkap, budidaya ikan, dan pengolahan hasil perikanan, serta adanya ekosistem estuari atau kawasan mangrove yang mampu menunjang keberhasilan usaha perikanan tersebut.

Data luas genangan dan luas daratan akibat naiknya muka air laut yang diprediksi di tahun yang akan datang, dapat dilihat pada Tabel 2 . Sebaran mangrove pada tahun 2014, yang dapat dilihat pada Tabel 3. 
Tabel 3. Sebaran Mangrove di Wilayah Bangkalan

\begin{tabular}{ccccccc}
\hline No & Kecamatan & $\begin{array}{c}\text { Sangat Padat } \\
(>\mathbf{1 5 0 0} \\
\text { pohon/Ha) }\end{array}$ & $\begin{array}{c}\text { Sedang } \\
(>=1000 \\
<\mathbf{1 5 0 0} \\
\text { pohon/Ha) }\end{array}$ & $\begin{array}{c}\text { Jarang } \\
(<1000 \\
\text { pohon/Ha) }\end{array}$ & Total & $\%$ \\
\hline 1 & Bangkalan & 104,6 & 26,8 & 88,9 & 220,3 & 14,6 \\
\hline 2 & Arosbaya & 56,8 & 11,3 & 51,2 & 119,3 & 7,9 \\
\hline 3 & Sepulu & 22,9 & 20,1 & 111,1 & 154,1 & 10,2 \\
4 & Socah & 11,9 & 9,3 & 64,5 & 85,8 & 5,7 \\
5 & Kamal & 11,6 & 11,6 & 210,3 & 233,4 & 15,5 \\
6 & Tanjungbumi & 0,9 & 0,7 & 4,1 & 5,7 & 0,4 \\
7 & Klampis & 76,3 & 50,1 & 381,2 & 507,6 & 33,7 \\
8 & Kwanyar & 6,8 & 4,1 & 24,9 & 35,8 & 2,4 \\
9 & Modung & 58,0 & 24,2 & 64,0 & 146,2 & 9,7 \\
\hline & Jumlah & 349,7 & 158,2 & $1.000,2$ & $1.508,1$ & 100,0 \\
\hline
\end{tabular}

Sumber: Zainuri et al. (2014)

Tabel 4. Sebaran Spesies Mangrove di Kecamatan Arosbaya

\begin{tabular}{|c|c|c|c|c|c|c|c|}
\hline \multirow{3}{*}{ No } & \multirow{3}{*}{ Nama Spesies } & \multicolumn{6}{|c|}{ Tingkat Sebaran } \\
\hline & & \multicolumn{3}{|c|}{ Pantai Desa Tengket } & \multicolumn{3}{|c|}{ Pantai Desa Lajing } \\
\hline & & Tinggi & Sedang & Rendah & Tinggi & Sedang & Rendah \\
\hline 1 & Avecenniaalba & $\sqrt{ }$ & & & & $\sqrt{ }$ & \\
\hline 2 & Avicennia lanata & & $\sqrt{ }$ & & & & $\sqrt{ }$ \\
\hline 3 & Sonneratia caseolaris & & $\sqrt{ }$ & & & & $\sqrt{ }$ \\
\hline 4 & Xylocarpus granatum & & & $\sqrt{ }$ & & $\sqrt{ }$ & \\
\hline 5 & Ceriops tagal & $\sqrt{ }$ & & & & $\sqrt{ }$ & \\
\hline 6 & Rhizopora apiculata & $\sqrt{ }$ & & & & $\sqrt{ }$ & \\
\hline 7 & Rhizopora stylosa & & $\sqrt{ }$ & & & & $\sqrt{ }$ \\
\hline 8 & Rhizopora mucronata & $\sqrt{ }$ & & & & $\sqrt{ }$ & \\
\hline 9 & Sonneratia alba & & $\sqrt{ }$ & & & & $\sqrt{ }$ \\
\hline 10 & Lumnitzera littorea & & $\sqrt{ }$ & & & & $\sqrt{ }$ \\
\hline 11 & Aegiceras corniculatum & & & $\sqrt{ }$ & & & $\sqrt{ }$ \\
\hline 12 & Camptostemon schultzii & & $\sqrt{ }$ & & & & $\sqrt{ }$ \\
\hline
\end{tabular}

Data sebaran spesies mangrove berdasarkan pengamatan yang telah dilakukan bersama dengan
POKMASWAS dapat dilihat pada Tabel 4. 


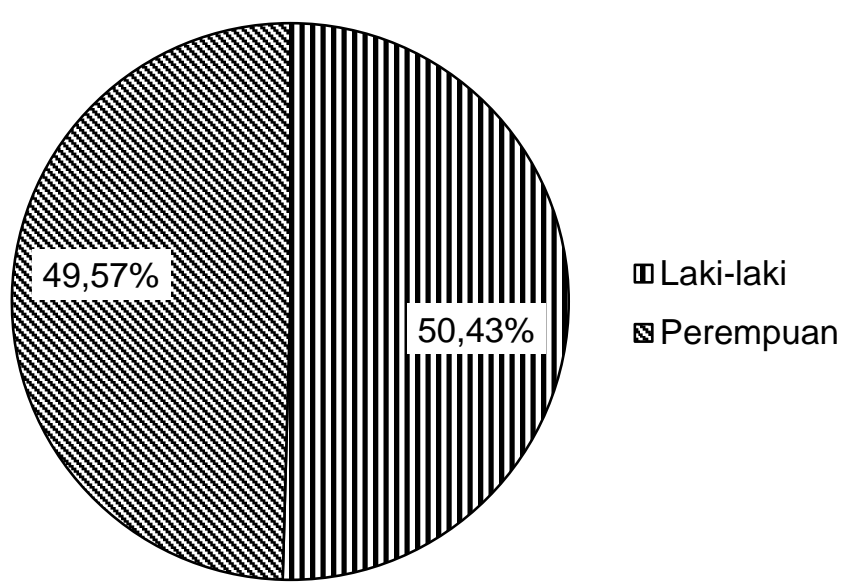

Gambar 2. Jumlah Penduduk Menurut Jenis Kelamin

Tabel 6. Jumlah Penduduk Berdasarkan Kelompok Umur

\begin{tabular}{ccccc}
\hline No & Umur & Laki-laki & Perempuan & Jumlah \\
\hline 1 & $0-19$ & 10.470 & 10.749 & 21.219 \\
2 & $20-64$ & 16.099 & 16.784 & 32.883 \\
3 & $65+$ & 2.108 & 2.236 & 4.344 \\
\hline & & Jumlah & 58.446 \\
\hline
\end{tabular}

Tabel 7. Jumlah Pelaku Usaha di Kecamatan Arosbaya

\begin{tabular}{llccc}
\hline & & \multicolumn{3}{c}{ Jumlah Pelaku } \\
\cline { 3 - 5 } No & \multicolumn{1}{c}{ Desa } & Budidaya & Pengolah & Nelayan \\
\hline 1 & Arosbaya & - & 17 & 334 \\
2 & Tengket & 36 & 14 & 367 \\
3 & Lajing & - & - & 68 \\
4 & Dlemer & & 31 & 3 \\
\hline & Total & $\mathbf{3 6}$ & $\mathbf{3 1 2}$ \\
\hline
\end{tabular}

Kondisi Potensi dan Permasalahan Sumberdaya Manusia

Jumlah penduduk Kecamatan Arosbaya berdasarkan data laporan kependudukan kecamatan tercatat 58.446 jiwa yang terdiri dari 29.477 lakilaki dan 28.969 perempuan. Berikut disajikan persentase jumlah penduduk menurut jenis kelamin di Kecamatan Arosbaya yang dapat dilihat pada Gambar 2.

Data jumlah penduduk berdasarkan kelompok umur yang berada di Kecamatan Arosbaya pada Tabel 6. Jumlah pelaku usaha di 
Tabel 8. Rata-rata Karakteristik Responden

\begin{tabular}{llccc}
\hline No & Responden & Umur (Tahun) & Pengalaman Kerja (Tahun) & Pendidikan \\
\hline 1 & Nelayan & 42 & 18 & SD \\
2 & Pembudidaya & 36 & 12 & SMA \\
3 & Pengolah & 35 & 16 & SD \\
\hline
\end{tabular}

Tabel 9. Harga Ikan Hasil Tangkapan Nelayan

\begin{tabular}{llc}
\hline No & \multicolumn{1}{c}{ Jenis Ikan } & Harga (Rp)/ Kg \\
\hline 1 & Ikan Bawal Hitam & $80.000,-$ \\
2 & Ikan Bawal Putih & $180.000,-$ \\
3 & Ikan Laosan & $40.000,-$ \\
4 & Ikan Gerabah & $39.000,-$ \\
5 & Ikan Belanak & $35.000,-$ \\
6 & Rajungan & $60.000,-$ \\
7 & Kerang & $25.000,-$ \\
\hline
\end{tabular}

Tabel 10. Hasil Produksi Perikanan Budidaya per-Siklus

\begin{tabular}{llcccc}
\hline $\begin{array}{c}\text { Bidang } \\
\text { Perikanan }\end{array}$ & $\begin{array}{c}\text { Jenis Usaha } \\
\text { Pembesaran }\end{array}$ & $\begin{array}{c}\text { Jumlah } \\
\text { Panen } \\
\text { (ekor) }\end{array}$ & SR (\%) & $\begin{array}{c}\text { Produksi } \\
\text { (kg) }\end{array}$ & $\begin{array}{c}\text { Harga } \\
\text { Jual (Rp) }\end{array}$ \\
\hline Budidaya & Ikan Bandeng & 7.000 & 70 & 1.400 & 25.000 \\
\cline { 2 - 6 } & Ikan Lele & 1.800 & 90 & 225 & 22.000 \\
\hline
\end{tabular}

Kecamatan Arosbaya dapat dilihat pada tabel 7.

Karakteristik responden dalam penelitian ini meliputi: (1) umur responden, (2) pengalaman kerja, dan (3) pendidikan responden. Data mengenai karakteristik responden di Kecamatan Arosbaya pada Tabel 8.

Kondisi Umum Usaha Perikanan

Daftar harga ikan hasil tangkapan nelayan di Kecamatan Arosbaya pada
Tabel 9. Hasil survei nilai produksi pada kedua kegiatan budidaya dapat dilihat pada tabel 10.

Analisis Usaha

Data hasil akumulasi yang disajikan pada Gambar 3.

\section{Identifikasi Permasalahan}

Selain terdapat potensi-potensi yang menunjang keberhasilan usaha tersebut, juga terdapat beberapa 


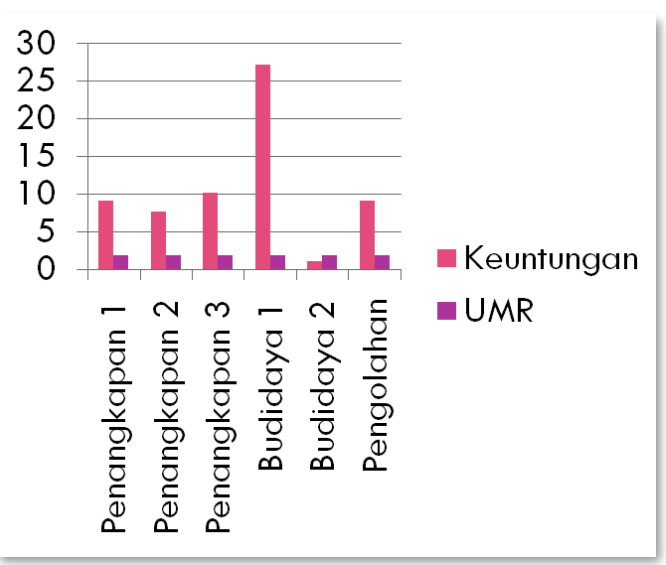

Gambar 3. Diagram Perbandingan Nilai Keuntungan dengan UMR Kabupaten Bangkalan

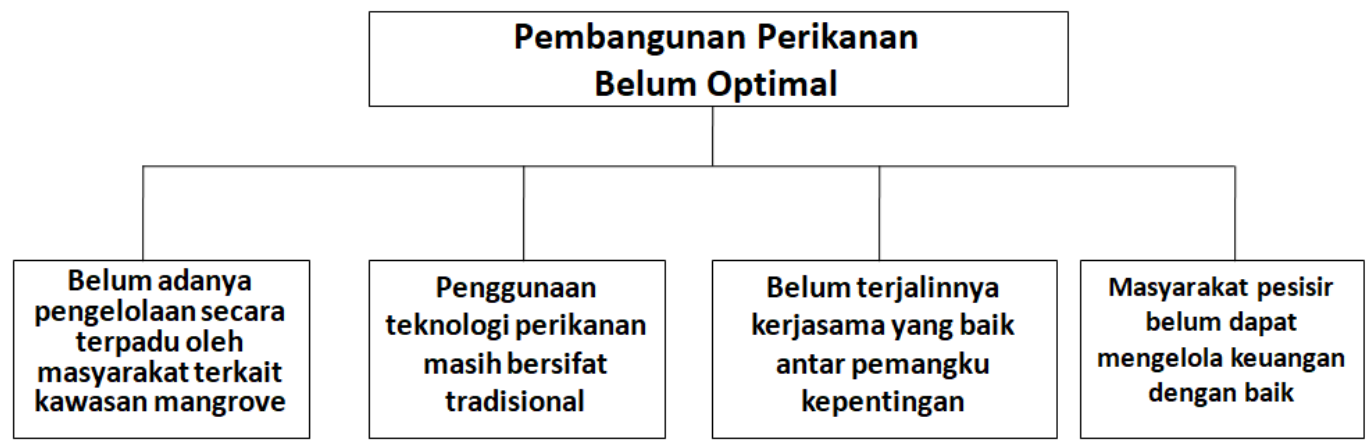

Gambar 4. Permasalahan Pembangunan Perikanan Kecamatan Arosbaya Secara Umum

permasalahan yang dapat dijadikan sebagai bahan evaluasi dalam melakukan pembangunan perikanan secara berkelanjutan. Identifikasi permasalahan dilakukan dengan metode tree analysis (Asmoko 2019). Permasalahan-permasalahan yang teridentifikasi disajikan pada Gambar 4.

\section{Pembahasan}

Kondisi Potensi dan Pengelolaan Pesisir

Potensi sumber daya alam yang dapat digunakan dibidang budidaya perikanan yaitu terdiri dari areal perikanan tambak (Fishpond) sebesar 31 Ha dan area kolam (Pond) sebesar 0,04 $\mathrm{Ha}$ (BPS Kab. Bangkalan 2018). Potensi tersebut cukup baik untuk dapat dimanfaatkan secara optimal dengan berbagai pertimbangan dan kaidahkaidah yang ada. Akan tetapi, SDA yang ada belum secara optimal dapat dimanfaatkan dan dikelola oleh masyarakat. Hal ini menjadi pekerjaan rumah (PR) yang besar bagi desa, kecamatan, penyuluh, bahkan bagi 
Dinas Perikanan Kabupaten Bangkalan dalam pengembangan dan pengelolaan potensi yang ada.

Pada hasil observasi dilapangan, menunjukkan bahwa pengelolaan pesisir Kecamatan Arosbaya cenderung tidak terlihat dan belum dilakukan secara optimal. Hal ini juga disampaikan oleh ketua POKMASWAS Arosbaya yang bergerak dalam melakukan pengawasan pada setiap aktivitas masyarakat sekitar, khususnya dibidang kelautan dan perikanan. Berdasarkan pengamatan dari (Syah 2019), diprediksi 20-50 tahun yang akan datang bahwa semua pantai di Kabupaten Bangkalan akan mengalami dampak dari naiknya muka air laut, salah satunya yaitu Kecamatan Arosbaya. Wilayah-wilayah yang diprediksi mengalami genangan tersebut akan terus meluas bahkan genangan tersebut akan terjadi di kecamatankecamatan lainnya.

Tabel 3, menunjukkan bahwa nilai sebaran mangrove di Kecamatan Arosbaya mencapai 119,3 pohon/ha, dengan kategori sangat padat 56,8 pohon/ha, sedang 11,3 pohon/ha, dan jarang 51,2 pohon/ha, sehingga didapatkan nilai persentase sebaran mangrove sebesar 7,9\%. Berbagai jenis spesies mangrove tumbuh pada $\pm 6,31$ $\mathrm{km}$ di sepanjang pantai Kecamatan Arosbaya (Sukandar et al. 2016), dengan jumlah \pm 12 spesies, yang diantaranya
Avecennia alba, Avicennia lanata, Sonneratia caseolaris, Xylocarpus granatum, Ceriops tagal, Rhizopora apiculata, Rhizopora mucronata, Rhizopora stylosa, Sonneratia alba, Lumnitzera littorea, Aegiceras corniculatum, dan Camptostemon schultzii.

Jika dilihat dari perbandingan jumlah penduduk laki-laki dan perempuan yang ada menunjukkan bahwa jumlah laki-laki lebih banyak dari pada jumlah perempuan. Perbandingan jumlah tersebut dapat berpengaruh terhadap lingkup pekerjaan masyarakat di wilayah tersebut. Selain itu, jumlah penduduk perempuan juga dapat mempengaruhi terhadap sumbangsi pembangunan ekonomi. Hal tersebut dapat dilihat dari besarnya peranan mereka sebagai angkatan kerja atau dalam istilah ilmiahnyatingkat partisipasi angkatan kerja (Setyowati, 2009).

Data tersebut, menunjukkan bahwa dari naiknya muka air laut akan mengakibatkan berkurangnya luas daratan. Sebagai contoh kasus di Pantai Bangkalan yang didalamnya juga termasuk Kecamatan Arosbaya, penurunan luas daratan juga akan diperburuk oleh abrasi pantai. Proses abrasi pantai dan genangan akibat naiknya muka air laut ini terjadi karena aktivitas-aktivitas yang dilakukan oleh masyarakat pesisir, sehingga 
meningkatkan tingkat kerentanan terhadap tingginya muka air laut seperti pertambakan, tanah yang landai, substrat pasir yang dapat mudah tergerus dan cepat membentuk genangan, serta menipisnya mangrove sebagai pelindung pantai alami yang ada di wilayah tersebut.

Kecamatan Arosbaya juga memiliki potensi yang sangat besar akan hutam mangrove yang ada, bahkan sampai saat ini perkembangannya dikategorikan masih baik. Namun, secara faktual belum adanya pengelolaan secara intensif dan terarah. Pada tahun 2008, sebaran luasan mangrove yang berada di Kecamatan Arosbaya tercatat 55,00 Ha (lqbal, Mahmudi, dan Risjani 2018). Setelah dilakukan studi lanjutan pada tahun 2014, diperoleh nilai total sebaran mangrove di Kabupaten Bangkalan sebesar 1.508,1 pohon/ha (Zainuri et al. 2014).

Berdasarkan data pada Tabel 4, dapat diketahui bahwa spesies Avecennia alba, Ceriops tagal, Rhizopora apiculata, dan Rhizopora mucronata memiliki tingkat sebaran yang tinggi di pantai Desa Tengket, sedangkan untuk Desa Lajing masih belum terdapat spesies yang memiliki tingkat sebaran yang tinggi, namun di pantai Desa Lajing lebih banyak ditemukan spesies mangrove Rhizopora apiculata. Data tersebut didapatkan berdasarkan hasil observasi dan wawancara secara langsung dengan ketua POKMASWAS serta berbagai kajian-kajian dari referensi yang ada. Data sebaran tersebut menunjukkan bahwa jenis-jenis mangrove yang tumbuh di sepanjang pantai Arosbaya terdapat 12 jenis spesies. Hal ini sesuai menurut Amalia dan Indah (2011), bahwa telah ditemukan 11 spesies dari 6 famili tumbuhan mangrove. Berdasarkan hal tersebut, dapat menunjukkan bahwa di Kecamatan Arosbaya juga memiliki kekayaan SDA yang sudah lama tersimpan dan belum dikelola secara optimal. Beberapa pekan ini, mulai dilakukan rehabilitasi kawasan mangrove dengan program penanaman pohon mangrove yang dilakukan oleh Dinas Perikanan dan Kehutanan setempat.

Berdasarkan Undang-Undang No. 1 Tahun 2014 Tentang Pengelolaan Pesisir dan Pulau-Pulau Kecil, maka kawasan tersebut perlu dilakukan konservasi, dimana yang dimaksud yaitu upaya perlindungan, pelestarian, dan pemanfaatan Wilayah Pesisir dan PulauPulau Kecil serta ekosistemnya untuk menjamin keberadaan, ketersediaan, dan kesinambungan Sumber Daya Pesisir dan Pulau-Pulau Kecil dengan tetap memelihara dan meningkatkan kualitas nilai keanekaragamannya. Selain itu, untuk pemanfaatan pulaupulau kecil dan perairan di sekitarnya, 
maka diprioritaskan beberapa kegiatan seperti: (1) konservasi; (2) pendidikan dan pelatihan; (3) penelitian dan pengembangan; (4) budidaya laut; (5) pariwisata; (6) usaha perikanan dan kelautan serta industri perikanan secara lestari; (7) pertanian organik; (8) peternakan; dan (9) pertahanan dan keamanan negara. Adanya undangundang tersebut dapat mendukung masyarakat pesisir yang berada disekitarnya untuk turut berpartisipasi dan terjun langsung dalam melakukan pengelolaan ekosistem mangrove yang ada. Masyarakat pesisir sebagai pemangku kepentingan utama yang dimaksud yaitu para nelayan tradisional, nelayan modern, pembudidaya ikan, pengusaha pariwisata, pengusaha perikanan, dan masyarakat umum (PERMEN-KP No. 23 Tahun 2016).

\section{Kondisi Potensi dan Permasalahan Sumberdaya Manusia}

Informasi mengenai jumlah penduduk sangat penting untuk perencanaan pembangunan perikanan khususnya untuk mengetahui peluang pasar (Riyadi 2004). Tabel 6 menunjukkan bahwa kelompok umur di Kecamatan Arosbaya terbagi menjadi tiga bagian yaitu kelompok (1) anakanak, (2) Dewasa, dan (3) Manula. Data ini merupakan kondisi yang dapat disebut sebagai bonus demografi, artinya suatu fenomena dimana struktur penduduk sangat menguntungkan dari sisi pembangunan karena jumlah penduduk usia produktif sangat besar, sedangkan jumlah usia kecil dan usia lanjut belum terlalu banyak. Penduduk dikatakan produktif apabila usia sudah berkisar 15-64 tahun (Sukmaningrum dan Imron 2017).

Secara ekonomis, masyarakat Arosbaya sebagian besar bekerja sebagai petani, buruh, jasa, nelayan, pengolah, PNS/ TNI/POLRI, dan lainlain. Melalui kegiatan usaha yang dibangun dalam sektor perikanan, tentunya juga dapat memberikan kontribusi terhadap pembangunan ekonomi Kecamatan Arosbaya. Hal ini sesuai menurut (Mudzakir 2010), bahwa sektor perikanan juga memberikan kontribusi terhadap pembangunan ekonomi di wilayah tersebut.

Berdasarkan data sekunder dari Dinas Perikanan Kabupaten Bangkalan, Kecamatan Arosbaya memiliki 839 rumah tangga perikanan (RTP) yang bergerak dibidang usaha penangkapan, budidaya dan pengolahan hasil perikanan. Berikut disajikan secara rinci mengenai jumlah pelaku utama perikanan yang dapat dilihat pada Tabel 7.

Para pelaku utama tersebut, telah terbentuk 12 kelompok perikanan yang terdiri dari Kelompok Usaha Bersama (KUB), Kelompok Budidaya Perikanan 
(POKDAKAN), Kelompok Pengolah dan Pemasar (POKLAHSAR), dan Kelompok Masyarakat Pengawas (POKMASWAS). Kelompok perikanan ini dapat mendukung dan menjadi wadah kerjasama bagi para pelaku utama dalam meningkatkan produksi serta berkontribusi terhadap pembangunan wilayah kedepannya. Adanya organisasi sosial tersebut, seluruh potensi sumber daya sosial budaya dan ekonomi masyarakat dapat terhimpun, dikelola, dan diberdayagunakan secara efektif untuk mendukung pemberdayaan masyarakat (Mala 2015).

Hasil penentuan jumlah responden untuk data analisis permasalahan perikanan menggunakan rumus Slovin (Setiawan 2007) jumlah sampel yang diambil yaitu sebanyak 42 orang responden. Sampel atau responden tersebut kemudian diambil secara merata dari tiga bagian sektor kegiatan perikanan yang ada di Kecamatan Arosbaya. Keseluruhan jumlah sampel tersebut terdiri dari 39 orang responden di sektor penangkapan, 2 orang responden di sektor budidaya, dan 1 orang responden di sektor pengolahan hasil perikanan.

Berdasarkan Tabel 8, karakteristik responden memiliki umur yang masih produktif dalam menjalankan sebuah usaha. Selain itu, rata-rata pengalaman kerjanya melebihi 10 tahun, artinya usaha yang dijalankan sudah cukup lama. Jika dilihat berdasarkan latar belakang pendidikannya, rata-rata pelaku utama masih rendah, khususnya pelaku utama yang bergerak di bidang perikanan tangkap dan pengolahan hasil perikanan. Hal tersebut dapat berpengaruh terhadap kinerja dari para pelaku utama tersebut, karena kinerja karyawan merupakan output dari penggabungan faktor-faktor yang penting yakni kemampuan, minat, dan motivasi seorang pekerja, serta semakin tinggi faktor-faktor tersebut maka semakin besarlah kinerja seorang yang bersangkutan (Candra 2018). Selain itu, pendidikan, umur dan pengalaman kerja juga akan berpengaruh terhadap nilai pendapatan yang akan didapatkannya (Hermawan 2018).

Secara umum permasalahan terkait SDM yang didapatkan dari penelitian ini yaitu dengan kondisi sumberdaya alam yang semakin menurun, sedangkan sumberdaya manusia yang semakin meningkat setiap tahunnya, serta minimnya pengetahuan masyarakat terhadap pelestarian sumberdaya alam yang ada dapat mengakibatkan menghilangnya kelestarian sumberdaya hayati perikanan di wilayah tersebut. Maka hal ini menjadi PR (Pekerjaan Rumah) bagi semua pemangku kepentingan, baik dari masyarakat pesisir itu sendiri, 
Pemerintah ataupun Penyuluh yang bertugas dalam pengembangan SDM pada wilayah tersebut.

\section{Konsisi Umum Usaha Perikanan}

Kegiatan usaha perikanan di Kecamatan Arosbaya terbagi dalam tiga segmen usaha yang meliputi usaha yang bergerak dibidang penangkapan ikan, pengolahan hasil perikanan, dan budidaya ikan. Usaha Perikanan tersebut berjalan sehubung dengan adanya kualitas SDA yang memadai. Sistem usaha perikanan tentunya terdiri dari beberapa sub-sub sistem yaitu pasokan input, proses produksi, pemasaran, layanan pendukung, dan analisis usaha.

\section{Penangkapan Ikan}

Usaha penangkapan ikan di Kecamatan Arosbaya hanya ada di Desa Arosbaya, Tengket dan Lajing, karena desa tersebut yang berbatasan langsung dengan Laut Jawa. Masyarakat perikanan yang bergerak dibidang usaha penangkapan ini yaitu \pm 774 rumah tangga perikanan. Produksi dimulai dari pasokan input, proses produksi, dan pasca penangkapan.

Pada pasokan input produksi dilakukan dari persiapan bahan baku, modal, lokasi usaha, dan tenaga kerja. Bahan baku atau keperluan yang dibutuhkan oleh para nelayan diperoleh dari toko saprokan yang ada di
Kecamatan Arosbaya, terkecuali tidak adanya ketersediaan bahan atau sarana prasaran yang mencukupi. Modal yang digunakan oleh para nelayan merupakan modal mandiri, namun ada beberapa pelaku utama dengan modal berkelompok serta adanya bantuan dari Dinas Perikanan Kabupaten Bangkalan yang berupa dana alokasi khusus. Bantuan tersebut diberikan dalam bentuk alat dan barang yang diperlukan dalam kegiatan produksi. Usaha penangkapan ini berlokasi dari pesisir pantai Arosbaya sampai \pm 15 mill laut jawa.

Proses produksi dimulai dari menyiapkan alat tangkap dan perahu. Alat tangkap yang digunakan oleh para nelayan yaitu jaring rajungan, bubu, gill net, dan trammel net dengan target yang didapat yaitu rajungan, ikan bawal, udang, ikan laosan, ikan gerabah, ikan belanak, kerang-kerangan dan lain sebagainya. Jika dilihat berdasarkan Keputusan Menteri Kelautan dan Perikanan Nomor 06 Tahun 2010 tentang Alat Penangkapan Ikan, alat tangkap yang digunakan para nelayan Kecamatan Arosbaya masih ramah lingkungan atau termasuk dalam alat tangkap yang diperbolehkan oleh peraturan perundang-undangan. Kegiatan penangkapan berlangsung selama satu hari (One Day Fishing). Asumsi nelayan melaut dalam 1 tahun yaitu 10 bulan,sehingga dalam 1 bulan 
tersebut nelayan pergi melaut sebanyak 30 trip. Kapal yang digunakan 1-3 GT, dengan bahan kayu, dan mesin yang digunakan adalah jenis mesin tempel dengan kekuatan 7-11 PK. Pada setiap kapal memuat 1-3 orang, yang terdiri dari pemilik perahu dan 2 anak buah kapal. Selain itu, nelayan juga melakukan penyediaan bahan bakar (solar), umpan, dan penyediaan logistic (bekal nelayan).

Proses produksi yang dilakukan nelayan di laut yaitu setting dan hauling. Proses setting dilakukan secara manual \pm selama 20 - 30 menit sesuai ukuran alat tangkap yang digunakan oleh nelayan. Semakin besar alat tangkap yang digunakan, maka semakin lama waktu yang di butuhkan dalam sekali setting. Hauling merupakan proses penarikan jaring atau pancing, proses ini menghabiskan waktu dan tenaga yang banyak, karena berat dan harus melepaskan hasil tangkapan dari jaring atau bubu, kemudian disortir (dipisahkan sesuai dengan jenis dan berat ikan) yang nantinya akan di masukkan kedalam palka, dan diberi es sebelum dijual pada pengepul di daerah PPI (Pangkalan Pendaratan Ikan).

Pemasaran hasil tangkapan tersebut dilakukan dengan dua cara yaitu secara langsung dan tidak langsung. Secara langsung yaitu konsumen langsung mendatangi PPI, sedangkan tidak langsung yaitu hasil tangkapan nelayan dibeli oleh pengepul, yang kemudian pengepul menjual kembali ke grosiran dan dipasarkan ke konsumen di pasar tradisional ataupun di ekspor keluar daerah, seperti Surabaya, Jawa Tengah, Bali dan lain sebagainya.

\section{Budidaya Ikan}

Segmen usaha budidaya ikan berada di Desa Tengket, dengan komoditas ikan bandeng, udang vannamei, dan udang windu, namun sejak tahun 2015 produksi udang tidak lagi dilakukan, karena telah terjadi penurunan daya dukung tambak yang mengakibatkan pembudidaya enggan produksi. Sebagai alternatif agar usaha terus berjalan, maka usaha pembesaran bandeng terus dilanjutkan. Pada dua tahun ini, sudah mulai dikembangkan kegiatan pembesaran ikan lele, namun dilakukan sebagai sumber penghasilan sampingan dan terbatas hobi. Teknologi yag digunakan olah pembudidaya bandeng masih bersifat tradisional dengan menggunakan lahan tambak yang ada, sedangkan pada pembesaran ikan lele sudah menerapkan teknologi semi intensif, namun produksi tidak dilakukan secara berkelanjutan. Proses produksi pada kegiatan budidaya ini dilakukan mulai dari tahapan kegiatan yang meliputi: persiapan wadah, pemeliharaan benih, panen dan pasca panen. 
Kegiatan persiapan wadah dilakukan dengan seadanya, karena menganut pada kearifan lokal masyarakat yang tidak mau melakukan budidaya yang terkesan menyulitkan, serta adanya tuntutan pemenuhan target dan permintaan pasar. Persiapan dilakukan mulai dari perbaikan kolam, dan penyediaan sarana prasarana seperti: nener, pakan, obat-obatan, dan alat produksi. Sarpras diperoleh dari pasar lokal di Kecamatan Arosbaya.

Pada tahap pemeliharaan, nener ditebar pada kolam pembudidaya dengan kepadatan 1 ekor $/ \mathrm{m}^{3}$, dengan ukuran rata-rata 6-12 cm dan dipelihara selama 4-5 bulan. Pemberian pakan tidak dilakukan karena pembudidaya hanya mengandalkan pakan alami. Berdasarkan SNI 6148.2:2013 mengenai mutu benih, nener yang ditebar oleh pembudidaya termasuk dalam kategori Gelondongan III, namun padat tebar belum sesuai dengan SNI. Nener yang digunakan berasar dari Kecamatan Burneh dan Kuanyar. Pada budidaya ikan lele, benih yang ditebar berukuran sangkal dengan size 40-80, panjang 15$17 \mathrm{~cm}$, dan bobot rata-rata 20-25 g/ekor yang berasal dari pembudidaya lokal. Pemberian pakan dilakukan 2-3 kali/hari, dengan menggunakan pakan buatan (pellet). Total pakan yang diberikan selama 35-40 hari pemeliharaan yaitu \pm 240 kg. Secara umum teknologi penerapan dalam proses budidaya masih bersifat tradisional, sehingga para pembudidayatidak melakukan pengecekan kualitas air dan kurang memahami tentang pentingnya dan cara penanganan mengenai hama dan penyakit.

Proses pemanenan ikan bandeng dan lele dilakukan secara berkala, yaitu panen parsial dan panen total. Panen parsial dilakukan karena permintaan pasar yang sangat mendesak, sehingga pembudidaya melakukan panen sesuai kebutuhan konsumen saja. Panen total dilakukan apabila telah mencapai pada target yang telah ditentukan.

Tabel 10, menunjukkan hasil ratarata produksi ikan bandeng mencapai 1,4 ton/produksi dan ikan lele sudah mencapai porduksi rata-rata $180-200$ kg/produksi. Hargga jual yang ditetapkan pembudidaya bandeng yaitu $\mathrm{Rp}$. $25.000,-/ k g$, sedangkan pada ikan lele yaitu Rp. 22.000,-/kg. Pemasaran dilakukan hanya dengan dua alur pemasaran yaitu secara langsung dan semi langsung. Secara langsung yaitu para konsumen langsung mendatangi lokasi budidaya. Secara semi langsung, pengepul yang mendatangi pembudidaya, kemudian dijual kembali kepada konsumen. 
Pengolahan Hasil Perikanan

Kegiatan pengolahan hasil

perikanan di Kecamatan Arosbaya meliputi: pengolahan ikan asin (pengeringan ikan), pemindangan ikan, petis ikan, dan terasi. Pada pengolahan hasil perikanan ini, sampel yang diambil yaitu pengolahpindang ikan yang berada di Desa Arosbaya. Hal tersebut dilakukan, karena mayoritas kegiatan usaha dibidang pengolahan berada pada pengolahan ikan pindang. Pada kegiatan usaha pengolahan hasil perikanan ini dimulai dari pasokan input, proses produksi, pasca produksi sampai dengan pemasaran.

Pasokan input pada produksi pemindangan ikan ini meliputi: bahan baku, modal, tenaga kerja, dan lokasi usaha. Bahan baku yang digunakan yaitu ikan pindang bermutu segar yang diperoleh langsung dari hasil tangkapan nelayan, namun juga berasal dari luar daerah dikarenakan bahan baku yang kurang memadai. Ketersediaan bahan baku merupakan salah satu faktor penting bagi sebuah agroindustri dalam menjaga kualitas, kuantitas dan kesinambungan produksinya (Nurfitria, Syafii, dan Kuntadi, 2014). Rata-rata jumlah modal yang dikeluarkan yaitu sebesar Rp. 35.000.000,- yang berasal dari modal pribadi. Pada kegiatan usaha ini, sebagai tenaga kerja pengolahan pindang yaitu pemilik usaha.
Proses produksi dilakukan dari menyiapkan sarana dan prasarana, perhitungan bahan, sampai dengan proses pengolahan. Proses pengolahan dimulai dari perhittungan bahan, penyesuaian bahan baku dengan wadah, penambahan rempah-rempah, kemudian dilanjutkan dengan tahap pengukusan. Produksi dilakukan selama \pm 3 jam. Olahan ini masih dapat dilakukan secara tradisional, belum adanya teknologi terbaru dalam mendukung proses produksi. Para pengolah juga masih kurang paham terhadap penerapan sanitasi dan hygiene, serta belum adanya SOP dalam proses produksi.

Pada pasca produksi, hasil pengukusan kemudian diangin-anginkan dan dikemas secara rapi untuk dilakukan pemasaran. Hasil produksi dipasarkan pada pasar lokal ataupun di luar Kecamatan Arosbaya seperti: Klampis, Sepuluh, Tamberu, Bancaran, dan lainlainnya. Sistem pemasaran hasil produksi pindang ikan ini dilakukan secara langsung yaitu langsung dipasarkan pada konsumen.

Secara umum, pemasaran hasil produksi perikanan di Kecamatan Arosbaya terdapat dua alur distribusi pemasaran. Hal tersebut menjadi salah satu faktor penting untuk mendukung tercapainya target pemasaran, karena saluran distribusi merupakan saluran yang dipergunakan oleh produsen untuk 
menyampaikan atau menyalurkan barang yang dihasilkan melalui pos atau langsung mendatangi rumah konsumen (Kawileh 2014).

\section{Layanan Pendukung}

Sumber daya penunjang usaha perikanan di Kecamatan Arosbaya meliputi Pemerintah Kabupaten, Dinas Kelautan dan Perikanan Kabupaten Bangkalan, Koperasi, Perbankan dan toko Sarana Prasarana perikanan. Dinas Perikanan merupakan salah satu wadah masyarakat dalam mendukung pengembangan usaha perikanan dalam pembangunan perikanan yang berkelanjutan. Seiring berjalannya pembangunan sektor perikanan tersebut, pemerintah yang bekerjasama dengan Dinas Perikanan dan Kehutanan mulai melakukan program peduli lingkungan, sehingga sumber daya alam yang ada dapat dimanfaatkan secara berkelanjutan. Salah satu programnya yaitu peduli hutan mangrove yang ada di Kecamatan Arosbaya melalui kegiatan rehabilitasi mangrove (penanaman pohon mangrove) bersama masyarakat pesisir.

\section{Analisis Usaha}

Kondisi usaha perikanan sampai saat ini masih berjalan sesuai kondisi dilapangan, hanya saja perlu pengembangan teknologi dalam proses produksi. Berdasarkan hasil survei dan analisis usaha responden di lapangan menunjukkan bahwa usaha yang dijalankan layak untuk dilanjutkan. Hasil analisis usaha tersebut kemudian diakumulasi dalam bentuk diagram perbandingan nilai keuntungan dengan nilai UMR setempat.

Secara umum jika dibandingkan dengan nilai UMR sebesar Rp. 1.900.000, usaha yang dijalankan oleh para pelaku utama perikanan Kecamatan Arosbaya layak untuk terus dikembangkan. Pada penelitian ini, usaha penangkapan dibedakan menjadi 3 jenis usaha berdasarkan alat tangkap yang digunakannya yang meliputi: (1) kegiatan penangkapan dengan alat tangkap jaring rajungan, bubu, gill net, dan trammel net; (2) kegiatan penangkapan dengan alat tangkap gill net dan trammel net; (3) kegiatan penangkapan dengan alat tangkap bubu, gill net, dan trammel net. Pada usaha budidaya ikan dibedakan berdasarkan komoditas yang meliputi: (1) kegiatan pembesaran ikan bandeng; (2) kegiatan pembesaran ikan lele, sedangkan pada usaha pengolahan hasil perikanan peneliti hanya mengambil sampel pengolah ikan pindang sebagai potret potensi perikanan di Kecamatan Arosbaya. Berdasarkan diagram tersebut, menunjukkan terjadinya 
perbedaan yang signifikan, artinya usaha yang dijalankan para pelaku utama perikanan tergolong sudah mencapai target pendapatan minimum. Hanya saja terdapat satu kegiatan usaha yang masih belum mencapai target minimum/UMR yaitu kegiatan usaha pembesaran lele. Berdasarkan hasil survei menunjukkan bahwa tingkat fokus masyarakat dalam menjalankan usaha sangat dibutuhkan, sehingga dapat mempengaruhi nilaipendapatan yang dijalankannya. Hal ini sesuai menurut Igrisa (2010), bahwa disposisi atau sikap pelaksana yaitu merupakan komitmen dari aparat pelaksana untuk betul-betul melaksanakan setiap program yang telah ditetapkan.

Sebagian besar pelaku utama dalam kegiatan produksinya tidak melakukan perhitungan analisis usaha, sehingga hasil keuntungan dari pendapatan yang diperoleh tidak dapat kembangkan karena keuntungan yang didapatkan tidak menentu. Hal ini menjadi koreksi bagi para pelaku utama agar dapat melakukan perhitungan analisis usaha sebagaimana mestinya. Pada periode pengembangan usaha tentunya perlu memperhatikan nilai dampak terhadap lingkungan. Pemenuhan masyarakat dalam bentuk kesadaran diri agar dapat melestarikan lingkungan cenderung masih sangat minim. Hal ini dapat dilihat berdasarkan perlakuan dalam proses produksi, seperti belum adanya penanggulangan limbah sisa produksi, sampah dimana-mana, dan pengelolaan kawasan yang belum terarah.

\section{Kondisi Penyuluhan}

Kelembagaan Penyuluhan Perikanan Arosbaya berada di lingkup Dinas Perikanan Kabupaten Bangkalan guna melakukan koordinasi terkait pelaksanaan-pelaksanaan penyuluhan yang akan dilakukan. Wilayah kerjanya meliputi seluruh kawasan dilingkup Kabupaten Bangkalan yang berfungsi sebagai penghubung antara pelaku utama perikanan dengan pemerintah. Satminkal dari seluruh penyuluh perikanan Kabupaten Bangkalan berada di BP3 Banyuwangi.

Kegiatan penyuluhan di Kabupaten Bangkalan belum berjalan secara maksimal, karena tidak adanya programa penyuluhan tingkat Desa, Kecamatan, maupun di tingkat Kabupaten, sehingga masing-masing penyuluh membuat sendiri rencana kerja yang akan dilakukan pada wilayah binaannya. Sebagai dasar rencana kerja yang disusun oleh penyuluh tersebut, berasal dari semua permasalahan para pelaku utama yang didapatkan dengan cara diskusi atau pertemuan kelompok. Sebaran penyuluh perikanan di Kabupaten Bangkalan tercatat hingga 
bulan Oktober 2019 meliputi penyuluh PNS sebanyak 8 orang, penyuluh perikanan bantu (PPB) sebanyak 6 orang dengan wilayah kerja yang berbedabeda. Di Kecamatan Arosbaya terdapat 1 penyuluh PNS yaitu bapak Soegiono dengan kompetensi bidang keahlian penangkapan perikanan.

Penyelenggaraan penyuluhan yang dilaksanakan di Kecamatan Arosbaya, dilakukan dengan beberapa tahapan kegiatan penyuluhan yang meliputi: perencanaan, pelaksanaan dan evaluasi (pembinaan dan pengawasan). Sebagai target sasarannya yaitu para nelayan, pembudidaya, dan pengolah. Anggaran kegiatan penyuluhan berasal dari pusat (APBN), tidak lagi dari dana APBD atau pemerintah daerah. Hal ini dikarenakan bahwa kegiatan penyuluhan telah menjadi urusan pemerintah pusat sesuai pada Undang-Undang Nomor 23 Tahun 2014. Anggaran tersebut digunakan para penyuluh dalam bentuk penyusunan program-program kegiatan penyuluhan diberbagai lokasi kegiatan perikanan. Program-program tersebut antara lain yaitu pertemuan kelompok, pembinaan para pelaku utama perikanan, wawancara secara lisan (anjangsana) dan lain sebagainya.

Kegiatan penyuluhan lebih menarik dan materi penyuluhan lebih mudah sampai ke sasaran bila ada sarana prasarana yang menunjang kegiatan penyuluhan di tingkat desa atau kecamatan. Kondisi Penyuluhan Pasca Udang-Undang Nomor 23 tahun 2014 tentang Pemerintahan Daerah, Kondisi Penyuluhan seperti berada dipersimpangan jalan. Sesuai Undang-Undang tersebut bahwa penyelenggaraan penyuluhan perikanan menjadi urusan pemerintah pusat, sehingga penyuluh merasa kesulitan untuk dapat memfasilitasi kegiatan penyuluhan secara optimal.

\section{Identifikasi Permasalahan}

Hasil identifikasi permasalahan ini menunjukkan bahwa:

1) Masyarakat pesisir belum sepenuhnya dapat mengelola dan memanfaatkan sumber daya lingkungan (kawasan mangrove) secara lestari dan berkelanjutan, serta kurangnya kerjasama yang baik dan terarah antar pemangku kepentingan.

2) Penggunaan teknologi perikanan yang digunakan masyarakat pesisir masih bersifat tradisional.

3) Secara ekonomi masyarakat perikanan cenderung belum dapat mengelola keuangan dengan baik.

Hasil identifikasi permasalahan ini, kemudian dapat dijadikan sebagai acuan untuk melakukan kegiatan penelitian selanjutnya. Identifikasi masalah pada umumnya mendeteksi, melacak, 
menjelaskan aspek permasalahan yang muncul dan berkaitan dengan judul penelitian atau variabel masalah yang akan diteliti (Wijaya 2013).

\section{SIMPULAN DAN SARAN}

Kecamatan Arosbaya memiliki luas wilayah \pm 4.245,207 $\mathrm{Ha}$ dengan didukung adanya potensi SDA kawasan mangrove seluas 119,3 $\mathrm{Ha}$, sehingga dapat menunjang pembangunan kegiatan perikanan baik dalam usaha penangkapan ikan, budidaya, bahkan pengolahan hasil perikanan. Sumber daya manusia yang memiliki peranan penting dalam melakukan produksi di bidang perikanan tersebut, terdiri dari 839 rumah tangga perikanan, dan selebihnya adalah masyarakat pendukung dalam kegiatan perikanan atau disebut dengan masyarakat pesisir, sehingga perlu dilakukan pengembangan sumberdaya manusia dalam menunjang kegiatan perikanan dan potensi dapat terkelola secara terpadu.

Potensi-potensi tersebut juga perlu pembenahan terkait permasalahan yang dapat menjadi faktor penghambat dalam pembangunan perikanan. Permasalahan tersebut yaitu (1) secara teknis: penggunaan teknologi perikanan masih bersifat tradisional, (2) ekonomi: belum dapat mengelola keuangan dengan baik,
(3) sosial: belum terjalinnya kerjasama yang baik dan terarah antar pemangku kepentingan, dan (4) ekologis: belum adanya pengelolaan pada kawasan mangrove.

Berdasarkan identifikasi potensi wilayah yang telah dilakukan, maka perlu dikembangkan inovasi dalam mendukung keberhasilan kegiatan perikanan yang dapat menghasilkan keuntungan yang lebih besar. Serta perlu adanya peningkatan peranan masyarakat dalam mengelola SDA yang ada, seperti pemberdayaan masyarakat dalam melakukan pengelolaan kawasan mangrove secara ekologis, sosial, dan ekonomis.

\section{DAFTAR PUSTAKA}

Amalia, Filda, Yuliani, dan Novita Kartika Indah. 2016. “Keanekaragaman Tumbuhan Mangrove di Kawasan Pantai Tengket, BangkalanMadura." LenteraBio 5(1):20-24.

Asmoko, Hindri. 2019. "Analisis Pohon Masalah." Diambil 11 Desember 2019

(https://klc.kemenkeu.go.id/bdpimanalisis-pohon-masalah/).

BPS Kabupaten Bangkalan. 2018. Kabupaten Bangkalan Dalam Angka 2018. Bangkalan (ID): Badan Pusat Statistik. 
BPS Kecamatan Arosbaya. 2018. Kecamatan Arosbaya Dalam Angka 2018. Bangkalan (ID): Badan Pusat Statistik.

Candra, Heri. 2018. "Pengaruh Tingkat Pendidikan dan Masa Kerja terhadap Kinerja Karyawan pada PT Sibatel Silangkitang Barata Telekomunikasi [Skripsi]." Universitas Medan Area, Medan (ID).

Hermawan, M. Agus. 2018. "Pengaruh Tingkat Pendidikan dan Pengalaman Kerja Terhadap Produktivitas Kerja dalam Perspektif Ekonomi Islam (Studi Pada Karyawan PT. Indokom Samudra Persada) [Skripsi]." Universitas Islam Negeri Raden Intan Lampung, Lampung.

Igirisa, Irawati. 2010. Faktor-Faktor yang Menentukan Keberhasilan dalam Kebijakan Pengembangan Usaha Tani di Kabupaten Gorontalo. Gorontalo (ID).

Iqbal, Muhammad Nurdzat, Mohammad Mahmudi, dan Yenny Risjani. 2018. "Pemetaan Sebaran Hutan Mangrove dengan Teknologi Penginderaan Jauh dan Sistem Informasi Geografis di Kecamatan Bangkalan Provinsi Jawa Timur." JFLS 2(2):101-13.
Kawileh, Fahmi Ahmad. 2014. "Analisis Pengaruh Saluran Distribusi Langsung Dan Tidak Langsung Terhadap Volume Penjualan Tekstil Di PT. Sari Warna Asli Karanganyar [Skripsi]." Universitas Muhammadiyah Surakarta.

Mala, Syipah Khoeril. 2015. "Peran dan Dinamika Kelompok dalam Kehidupan Sosial Ekonomi Nelayan." Orasi Jurnal Dakwah dan Komunikasi 7(1):1-20. doi: 10.24235/orasi.v7i1.1003.

Mudzakir, Abdul Kohar. 2010. "Peranan Sektor Perikanan Pada Perekonomian Jawa Tengah: Analisis Input Output." SAINTEK PERIKANAN: Indonesian Journal of Fisheries Science and Technology 4(1):28-34. doi: 10.14710/ijfst.4.1.28-34.

Muhktasor, Raden Edi Sewandon, Daniel M. Rosyid, Mauludiyah, Dwi Soetjipto, Rifky E. Hardijanto, Susilo Raharjo, Soni Fahruri, Novirman S. Said, Siswanto, Widi A. Pratikto, dan Suwardi. 2016. Indonesia Poros Maritim Dunia. Pertama. diedit oleh Mukhtasor. Jakarta (ID). 
Nasriyah, dan Pigoselpi Anas. 2018. "Identifikasi Potensi dan Analisis Masalah Sumber Daya Perikanan di Kecamatan Nambo Kota Kendari Provinsi Sulawesi Tenggara." Jurnal Penyuluhan Perikanan dan Kelautan 12(2):81-94. doi: 10.33378/jppik.v12i2.102.

Nurfitria, Rosita, Imam Syafii, dan Ebban Bagus Kuntadi. 2014. "Manajemen dan Strategi Persediaan Bahan Baku Pada Agroindustri Tape 'Sumber Madu' di Desa Sumberpinang Kecamatan Pakusari Kabupaten Jember." Berkala IImiah Pertanian 1-9.

Permen KP No. 23 Tahun. 2016. Tentang Perencanaan Pengelolaan Wilayah Pesisir dan Pulau-Pulau Kecil.

Pratiwi, Wiwik D. 2007. "Participatory Rural Appraisal (PRA)." Diambil 20 Maret 2020

(http://dosen.ar.itb.ac.id/wdp/wpcontent/uploads/2007/04/1-PRAIndonesia.pdf).

Riyadi, Dedi M. Masykur. 2004. "Kebijakan Pembangunan Sumber Daya Pesisir Sebagai Alternatif Pembangunan Indonesia Masa Depan." Disampaikan pada Sosialisasi Nasional Program MFCDP 22.
Setiawan, Nugraha. 2007. "Penentuan ukuran sampel memakai rumus slovin dan tabel krejcie-morgan: telaah konsep dan aplikasinya." Diambil (http://pustaka.unpad.ac.id/wpcontent/uploads/2009/03/penentua n_ukuran_sampel_memakai_rumu s_slovin.pdf).

Setyowati, Eni. 2009. "Analisis Tingkat Partisipasi Wanita dalam Angkatan Kerja di Jawa Tengah Periode Tahun 1982-2000." Jurnal Ekonomi Pembangunan: Kajian Masalah Ekonomi dan Pembangunan 10(2):215. doi: 10.23917/jep.v10i2.801.

Sukandar, C. J., M. Handayani Harsindhi, Dewi CSU, Maulana AW, dan A. Bahroni Supriyadi. 2016. Profil Desa Pesisir Provinsi Jawa Timur, vol. 1 (Utara Jawa Timur). Surabaya (ID): Bidang Kelautan, Pesisir, dan Pengawasan Dinas Perikanan dan Kelautan Provinsi Jawa Timur.

Sukmaningrum, Adisti, dan Ali Imron. 2017. "Memanfaatkan Usia Produktif dengan Usaha Kreatif Industri Pembuatan Kaos pada Remaja di Gresik." Paradigma 5(3). 
Syah, Achmad Fachruddin. 2019. "Pengukuran Daerah Genangan Di Pesisir Bangkalan Akibat Naiknya Muka Air Laut [Pridiction Of Inundation Area At Bangkalan Coastal Region Resulted In Sea Level Rise]." Jurnal IImiah Perikanan dan Kelautan 5(1):67. doi: 10.20473/jipk.v5i1.11427.

Wijaya, Ari. 2013. "Kontribusi Hasil Belajar Produktif Agribisnis Perikanan Terhadap Kesiapan Praktek Kerja Industri Budidaya Perairan [Skripsi]." Universitas Pendidikan Indonesia.
Wirjohamidjojo, Soerjadi, dan Yunus Swarinoto. 2010. Iklim Kawasan Indonesia (Dari Aspek Dinamik Sinoptik). Jakarta (ID): Badan Meteorologi Klimatologi dan Geofisika.

Zainuri, M., Firman Farid Muhsoni, Ahmad Farid, dan Hafiluddin. 2014. Persembahan Prodi IImu Kelautan Universitas Trunojoyo Madura Untuk Maritim Madura. Bangkalan (ID): UTM Press. 